\title{
SHOULD HIGHER EDUCATION SUBSIDIES DEPEND ON PARENTAL INCOME?
}

\author{
ROBERT DUR \\ Tinbergen Institute, Erasmus University \\ COEN TEULINGS \\ Tinbergen Institute, University of Amsterdam \\ THIJS VAN RENS \\ Princeton University
}

\begin{abstract}
In many countries, student grants, tuition fees, and subsidized loans depend on parental income. This paper examines the efficiency and distributional effects of such conditioning, and assesses whether it is optimal practice when the government wants to reduce after-tax income inequality in the most efficient manner. Increasing the mean level of education among the work-force compresses wage differentials by level of education and thereby the pre-tax income distribution. Hence, subsidizing education may be part of an optimal redistribution policy. However, education subsidies mainly benefit high-ability students, limiting their redistributive virtues. Conditioning education subsidies on parental income may enable the government to reduce inframarginal subsidies, mainly benefiting high-ability students, while preserving the marginal subsidy, and thus the favourable effect on the mean education level which leads to wage compression.
\end{abstract}

\section{INTRODUCTION}

A review of student support in 13 countries by the Irish Department of Education and Science (2003, appendix 4) reveals that student grants, tuition fees, and subsidized loans are conditional on parental income in most countries. ${ }^{1}$ Although education is subsidized across the board, students from lowincome families receive larger subsidies for the same educational attainment. In the United States

1 The 13 countries examined in the report are Australia, Austria, Canada, Denmark, Finland, Germany, India, Ireland, the Netherlands, New Zealand, Sweden, the UK, and the USA. All of these countries subsidize education in one way or another. All except Ireland make subsidized loans available to students, in addition to grants or scholarships, either by providing state loans or by subsidizing the interest rate on loans provided through commercial banks. In most countries, all components of student support are conditional on parental income. Exceptions are Denmark, Finland, and Sweden, where the means test is based on the student's own income and not on parental income (in some other countries the same is true for students above a certain age); India, where grants are based on merit; and Austria, Germany, and the Netherlands, where loans (as opposed to grants) are not subject to any means test. 
(1999-2000), for instance, financial aid covered 64 per cent of the student budget for undergraduates from low-income families (less than \$30,000) and 53 per cent of the budget for students from middleincome families $(\$ 45,000-74,999)$. For low-income students a larger part of that aid consisted of grants instead of subsidized loans ( 39 per cent versus 23 per cent of their budget). ${ }^{2}$ Students from families in higher brackets of the income distribution at similar colleges still had about 45 per cent of their budget covered by financial aid and 12 per cent by grants (NCES, 2003).

This paper examines the efficiency and distributional effects of conditioning education subsidies on parental income. Is it optimal to do so? The main argument that has been used in the literature is that students from low-income families face credit constraints that prevent them from taking up an otherwise profitable education level. In that case, providing education subsidies conditional on parental income would be motivated by efficiency arguments. Empirical studies on the relation between parental income and children's educational attainment show a strong positive correlation. However, the evidence suggests that only a small part of the correlation can be attributed to short-run liquidity constraints. A large part of the correlation can be explained by long-run factors such as the genetic link between parents and children, a less stimulating learning environment in low-income families, or the inability of poor parents to provide moral support or to be good role models. ${ }^{3}$ Moreover, credit constraints are a weak argument for giving financial aid to low-income families with children in college. If credit constraints are to be the justification for education subsidies, then subsidized student loans are an efficient way to provide student support.

We explore a new argument for conditioning education subsidies on parental income, based on redistributive arguments. We build on previous work showing that education subsidies may be part of an optimal redistribution policy (Durand Teulings, 2001, 2003). The redistributive effect of education subsidies rests on imperfect substitutability in the demand for labour between workers with various levels of education. An increase in the mean level of education among the work-force reduces the wage of high-educated workers (since their supply goes up) and raises the wages of the low-educated workers (since their supply goes down). Overall, a higher mean education level therefore reduces wage differentials by level of education, implying a lower pre-tax wage inequality. With a lower pre-tax inequality, the same after-tax inequality can be attained with less progressive taxation. Now, both progressive taxation and education subsidies distort the labour market: the former reduces workers' effort below the optimal level (since workers get only part of the additional output), while the latter raises workers' take-up of education above the optimal level (since education is subsidized). The optimal redistribution policy trades off these distortions and applies a mix of both instruments.

However, there is a counteracting effect, which works against using education subsidies. High-ability students usually take up more education. Hence, if education is subsidized, the high-ability students benefit most. This counteracting effect of education subsidies leads to a widening, instead of a compression, of the income distribution. Simple solutions to this problem do not work well. One simple solution could be to subsidize only the lowest education level, such that every person would benefit equally from the subsidy. However, this would only raise educational attainment of the lowest ability type, which has only a small effect on the average education level of the work-force as a whole and leaves unexploited a large part of the potential contribution of education subsidies to raising the education level and hence to redistribution. An alternative solution is to take advantage of the correlation between student's future income and ability. Since this correlation is high, student's own future income is a good proxy for ability. Then, we could make education subsidies dependent on future labour income: the higher the future labour income, the lower the subsidy. This can be done by making part of the subsidy a grant and the rest a loan. The lower the future income, the higher the grant part. However, this idea is counterproductive for two reasons. First, conditioning education subsidies on future labour

\footnotetext{
${ }^{2}$ Figures for students attending a 4-year public non-doctoral college, see Table 11 in NCES (2003).

${ }^{3}$ There is considerable uncertainty about the relative weight of these long-run factors; see, for example, Mayer (2002) and Plug and Vijverberg (2003). Most of the economics literature, including this paper, lumps all long-run factors together under the term 'ability'.
} 
income is equivalent to raising the future marginal tax rate. Hence, it will reduce effort later in the worker's career. Moreover, the tax of future labour income also makes the take-up of education less attractive (since an important purpose of education is to raise future earnings). Hence, it works against the goal of having education subsidies in the first place. The only reason for making education subsidies conditional on own future income might be that this provides insurance for risky investment in human capital. The government can diversify risks from investing in education that individual students cannot insure against.

An alternative way to overcome the counteracting effect of inframarginal education subsidies is to exploit the inter-generational correlation in income. Because of this correlation, conditioning on parental income may be a good alternative to conditioning on the student's own future income, as long as parents do not take into account the adverse effects of their labour supply and schooling decisions on the tax regime faced by their (future) children, or at least, do so only partially. This conditioning on parental income enables the government to reduce inframarginal education subsidies to students who would stay in education anyway, and which benefit mainly the high-ability students.

The plan for this paper is as follows. We discuss the evidence for liquidity constraints and their effect on educational attainment in section II. Section III briefly summarizes our previous work showing that promoting education may reduce income equality and then examines whether conditioning on parental income renders education subsidies more effective in reducing inequality. In section IV we consider the question of whether conditioning education subsidies on education level or the student's own future income may be more efficient than conditioning on parental income. Section V concludes.

\section{CAPITAL-MARKET IMPERFECTIONS}

Much of the economics literature on education subsidies has focused on the role of capital- and insurance-market imperfections in human-capital formation. Whereas rich families may have sufficient means to pay for tuition fees and cost of living of their children while at college, poor families' offspring may have to rely on loans. With a wellfunctioning capital market, this would not be a problem. However, with imperfections in the capital market, poor families may face severe borrowing constraints.

If getting an education is a good investment, then why would banks not be willing to provide loans to students? The problem is that unlike physical capital, human capital cannot be collateralized. Because education cannot be expropriated by the bank when the student fails to repay her loan, the default risk on student loans is much higher than on mortgages, for instance. Higher default risk translates into higher interest rates, so the cost of education is higher for students from low-income backgrounds who have to borrow money to finance their education, resulting in suboptimally low investments in human capital.

\section{(i) Empirical Evidence}

Spurred by early empirical evidence that income is more equally distributed within wealthier countries, and Persson and Tabellini's (1994) finding that equality is positively correlated not only with the level but with the growth rate of per-capita income as well, it has become a fairly common assumption in the literature that there are at least some workers who under-invest in education because of creditmarket imperfections (Galor and Zeira, 1993; Benabou, 1996,2000,2002; Owen and Weill, 1998; Maoz and Moav, 1999; Janeba, 2000; Galor and Moav, 2000). In these models the most effective subsidies are aimed specifically at the lower tail of the income distribution, since that is where credit constraints are binding.

But the empirical literature, which uses mostly micro-data, is divided on the importance of credit constraints as an impediment for children from lowincome families to obtain an efficient level of education. The empirical difficulty is in assessing how much of inter-generational correlation in education and income levels can be attributed to correlation in ability and how much to credit constraints.

Cameron and Heckman (1998) and Carneiro and Heckman (2002) estimate the effect of family income on college attendance from the differences in attendance between quartiles of the parental 
income distribution, controlling for ability using data on test scores. They find that ability accounts for almost all of the gap in college attendance between minority and majority students. They also find that the effect of tuition levels on attendance is much weaker when controlling for ability and that there is hardly any difference in this effect across quartiles of the parental income distribution. These results suggest that ability is the relatively more important factor than short-run liquidity constraints in explaining the effect of parental income on educational attainment. Their estimates suggest that, at most, 8 per cent of the total US population is liquidity constrained, and that ability is the most important factor driving the correlation between education level and parental income.

Rather than directly trying to control for ability, Shea (2000) uses instrumental variables. He estimates a regression of schooling on parental income and a set of demographic controls. His instruments (union status, industry and job loss due to plant closures) affect parental income but are arguably uncorrelated with ability. He finds fathers' earnings have no significant effect on schooling, which he interprets as evidence against credit constraints. There is, however, a significant effect in the poverty subsample, suggesting that, for some families, financial constraints may be important.

Acemoglu and Pischke (2001) exploit the increase in earnings inequality in the USA in the 1980s as a natural experiment. They correlate the fraction of children attending college in different quartiles of the income distribution, different regions in the USA, and at different times, with average family income, controlling for quartile, region, and time fixed effects. They find large effects of family income on educational attainment over and above the quartile effects (a 10 per cent increase in family income increases the probability that children go to college by about one and a half percentage point).
Finally, there are some indirect pieces of evidence. The fact that students from low-income backgrounds work while they are in college more often than students from middle- or high-income families (NCES, 2003), might be interpreted as an indication that low-income families face liquidity constraints. If they are not credit constrained, then why would these students work while they are still in college, when their wage is likely to be much higher after graduation? Keane and Wolpin (2001) study the effect of credit constraints on attendance. They argue that, even though low-income families may face credit constraints, these do not affect educational attainment because students can alleviate these constraints by working while in college. ${ }^{4}$

Summarizing, the empirical evidence suggests that low-income families face credit constraints when deciding whether or not to send their children to college. It is unclear, however, how important these constraints are as an impediment to students from low-income families obtaining an efficient education level. If 8 per cent of the population is liquidity constrained when making the choice whether or not to send their children to college, as Carneiro and Heckman (2002) find for the USA, and assuming that the children in these families obtain 2 years of education less than they would have otherwise for this reason, then the average education level would be 0.16 years lower than optimal. To put this number into perspective, 0.16 years is about 5 per cent of the cross-country standard deviation of average education levels and twice the average yearly increase in the world-wide average. Carneiro and Heckman conclude, therefore, that 'short run income constraints play a role, albeit a quantitatively minor one. There is scope for intervention to alleviate these short term constraints' (p. 707).

But the main qualification in Carneiro and Heckman is not that credit constraints do not matter, but that short-run liquidity constraints are relatively unim-

\footnotetext{
${ }^{4}$ As another piece of indirect evidence, Card (2001) and Krueger (2004) argue that the fact that instrumental variables (IV) estimates for the return to schooling tend to be higher than ordinary least squares (OLS) estimates, suggests that the return to schooling for the groups most affected by the instruments (compulsory schooling laws, proximity to schools, tuition costs) is relatively high. This would suggest that the costs of schooling are relatively high for those groups, which is consistent with credit constraints causing these students to under-invest in their education. Second, the fact that the private return to investments in human capital exceeds that in physical capital seems also to point in that direction. However, both arguments seem questionable. Carneiro and Heckman (2002) argue that there are other models consistent with the finding that the IV estimates exceed the OLS estimates. They find the second argument unconvincing because the Mincerian return to schooling is not necessarily equal to the internal rate of return to investments in education and, therefore, cannot be directly compared to the return on physical capital.
} 
Figure 1

Financial Aid to Students in Tertiary Education

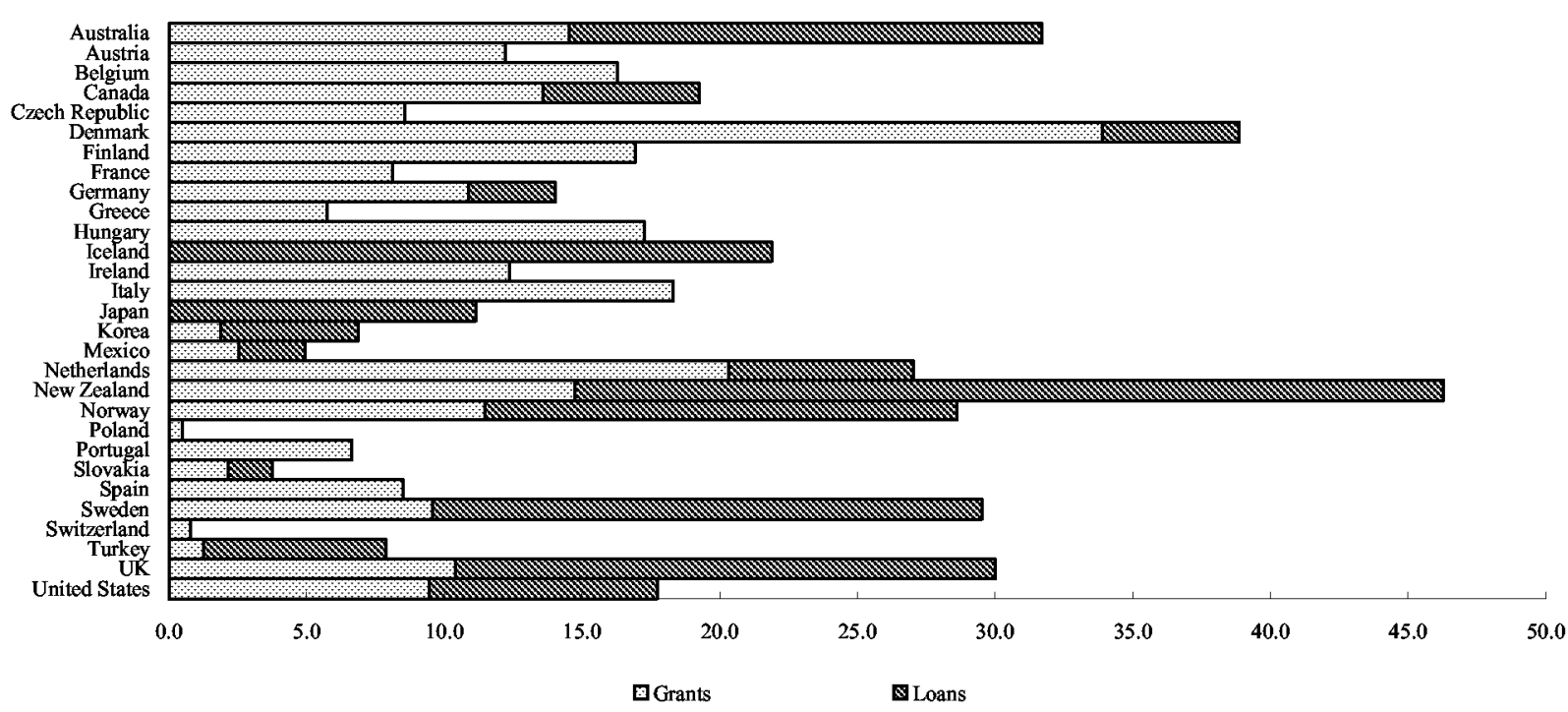

Source: OECD (2003, Table B5.2).

portant compared to long-run factors which in the empirical estimates show up as ability. They argue that much of the disadvantage of children from lowincome families is realized in the 'formative years' earlier in childhood. This interpretation is consistent with research in other social sciences, arguing that poverty may limit parents' ability to be 'good role models', or that poverty may make parents stressed, which limits their ability to be 'good parents'. The lack of moral support by poor parents may result in low educational achievement by their children (Mayer, 1997, 2002). ${ }^{5}$

This kind of argument has implications for humancapital policies. If most of the disadvantage of children from low-income families is realized in the formative years earlier in childhood, the optimal policy would call for a general redistribution of income to all low-income parents with young children, rather than conditioning higher education subsidies on parental income. Carneiro and Heckman note that 'By the time individuals finish high school, and scholastic ability is determined, the scope of tuition policy for promoting college attendance through boosting cognitive and non-cognitive skills is greatly diminished' (p. 709). In fact, by conditioning income supporton schooling, the policy may not help the children who suffer most from parental stress and from lack of a good role model, as those children are most likely to drop out of school at an earlier stage.

\section{(ii) Grant or Loan?}

If credit-market imperfections are preventing individuals from obtaining sufficient education, the following question naturally presents itself. Why, instead of subsidizing education, does the government not step in and provide credit to students? A loan scheme may be more equitable than a grant conditional on parental income, because the latter only favours poor families that gave birth to talented children.

The first answer to this question is that governments do, in fact, provide credit. As illustrated in Figure 1, most OECD countries provide loans as well as grants to students in tertiary education. ${ }^{6}$

\footnotetext{
${ }^{5}$ A potentially serious endogeneity problem is present here, which has not yet been settled in the empirical literature. While it may well be that poverty affects parents' abilities or mental stress, the causality may also run in the opposite direction. The few empirical studies testing these hypotheses all show very small effects.

${ }^{6}$ Both grants and loans are much less common for students in primary and secondary education, which is subsidized mainly through the institutions (OECD, 2003).
} 
The next thing to notice is that the distinction between loans and subsidies is in some sense fairly arbitrary. If the government provides loans to students from low-income families at a lower interest rate than commercial banks, then it implicitly subsidizes these students. Another way to see this is that if not all of the loans that are taken up will be paid back, the government incurs the cost of these defaults and, hence, a loan scheme will also entail some redistribution and a tax cost. Is there any difference then, between providing subsidized loans or direct subsidies or grants to students? To answer that question, we need to be explicit about what type of market imperfection leads to students from low-income families being credit constrained.

One reason for imperfections in the capital market is that people have heterogeneous solvency risk profiles which are hard to assess by banks. When people are better informed about their solvency risk than banks, and higher-risk types are willing to pay a higher interest rate than lower-risk types, the capital market may easily break down as the interest rate goes up, since only the relatively high-risk types will still opt for a loan. In response to this, banks may ration credit rather than increase the interest rate, as they anticipate that an increase in the interest rate will drive out the good risks from the market (Stiglitz and Weiss, 1981). ${ }^{7}$ As a result, there will be under-investment in human capital.

Clearly, a loan scheme offered by the government also suffers from the problem that it is particularly attractive to high-risk types. In contrast to commercial banks, however, the government can finance expected losses on the loan scheme by raising taxes. Thus, a loan scheme will redistribute resources from tax payers to high-risk types. As at least part of the loans will be paid back, the tax cost will, of course, always be lower than if the government would provide the same amount of student support through grants.

As an alternative interpretation, credit-market imperfections may result from a missing insur- ance market. Missing insurance markets are particularly relevant if risk aversion declines with income. If low-income families are less able or willing to bear the risk of investing in education, this may cause them to under-invest, even if they face the same interest rate as other families. If this is the case, the optimal human capital policy would provide subsidized loans to students, with repayment conditional on future income. That way, the government would take on the risks of investing in education. Because the government, unlike individual students, can diversify that risk, such a scheme would be welfare improving (Jacobs and Van Wijnbergen, 2003).

Another problem of missing insurance markets shows up when poor parents are, on average, less well able to assess the cognitive abilities of their children than rich parents, for example, because they did not get a higher education themselves. Then, children from low-income families may decide to obtain less education, as the return to that investment is surrounded by more uncertainty. Again, a loan scheme with future income-contingent repayment would be the tailor-made solution. Adrawback of income-contingent repayment is that it is equivalent to an income tax, and therefore causes similar distortions. First, it distorts the labour-supply decision; second, it undermines the initial goal of raising the average education level, since a higher future income tax makes investing in education less profitable; and, third, it causes distortions in the type of study children choose, as the income-contingent repayment makes studies with a relatively high pecuniary return less attractive compared to studies with a lower or zero pecuniary return.

\section{EDUCATION SUBSIDIES AND REDISTRIBUTION}

In this section we explore a new argument for conditioning education subsidies on parental income. We build on previous work showing that general education subsidies may be part of an efficient redistribution policy (Dur and Teulings, 2001, 2003). Redistributive policies usually lead to some form of distortion, because the policy-maker

\footnotetext{
${ }^{7}$ Jacobs and van Wijnbergen (2003) have recently shown that if people are sufficiently risk averse, the adverse-selection problem need not show up, as higher interest rates drive out the bad risks instead of the good risks from the market.
} 
Figure 2

Supply and Demand for Human Capital in the Dur and Teulings (2001) Model

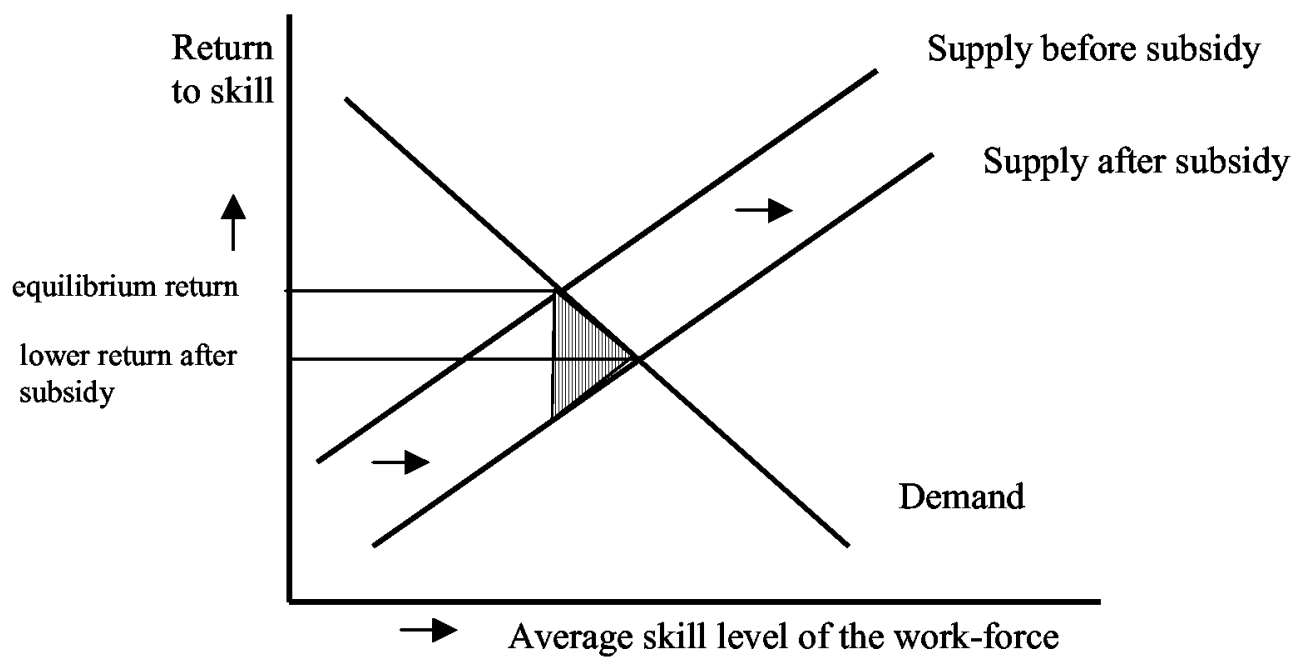

observes only the outcome of economic behaviour (e.g. income) and does not observe workers' characteristics (ability) that underlie the inequality in outcomes. Because the outcomes are endogenously determined by optimizing behaviour of individuals, taxing the outcomes induces people inefficiently to adjust behaviour so as to avoid a high tax burden. For example, progressive income taxation puts a tariff on labour supply, and will therefore reduce labour supply below its first-best level. An efficient redistribution policy seeks to apply that combination of policy instruments that achieves a given amount of redistribution at the lowest amount of distortions. Education subsidies might be part of this efficient policy, because these subsidies raise the average education level and may, therefore, reduce pre-tax wage differentials.

\section{(i) Wage-compression Effect}

The redistributive effect of education subsidies rests on a supply and demand effect. Since skill types are imperfect substitutes in production, relative wages depend on the supply of skills. As skills become more abundant in the economy, the return to skill falls, implying a flatter pre-tax wage distribution. Hence, by encouraging skill formation by schooling, the same after-tax income distribution can be attained with less progressive taxation. An efficient redistribution policy trades off the distortionary effect of progressive taxation and the distortions arising from education subsidies.
Figure 2 provides a graphical representation of the argument in the form of a simple supply and demand diagram. The return to investment in marketable skills, or the percentage increase in wage per additional unit of skill, is represented on the vertical axis. The average skill level of the work-force is represented on the horizontal axis. The equilibrium return to skill is determined by the intersection of the upward-sloping supply and the downward-sloping demand schedule. What determines the slope of both curves? The upward-sloping supply schedule reflects the choice of the mean ability type. Higherability types will acquire more marketable skill, lower-ability types less. The positive slope of this schedule is due to the choice behaviour of this mean ability type: he or she sets equal the marginal cost of obtaining an additional unit of skill (the time spent to acquire that skill) to its return. Each additional unit of skill takes more and more time to acquire, leading to the upward-sloping supply schedule. One way to establish that slope is to evaluate the effect of variations in the cost of education on the take-up of schooling, for example Stanley's (1999) and Dynarski's (2002) studies of the effect of the GI bill, which provided large subsidies to US veterans of the Second World War and the Korean war.

The negative slope of the demand curve reflects diminishing returns to education in aggregate production: each additional year of education produces less and less additional output. Diminishing returns to education are due to imperfect substitutability 
between types of labour. Having already ten engineers reduces the return to the eleventh engineer. As a result, when skills become more abundant in the economy, the return to skill falls.

If we subsidize education, people will choose to acquire more human capital, which reduces the return to human capital below its equilibrium level without subsidies. This is shown in Figure 2. This intervention leads to some distortion in the take-up of education, as some people obtain an education level for which the social cost exceeds the social benefit. In the graph, this welfare loss is represented by a standard Harberger triangle, the triangular area below the demand curve and between the two supply curves.

However, there is also a welfare gain from the subsidy. Only part of the effective human capital of an individual is determined by his or her(education) choices, the rest by other factors (such as innate ability) that are outside the control of the individual worker. It is this part of human capital that leads to social inequality. ${ }^{8}$ The reduction in the return to human capital does not only reduce the return to schooling, it also reduces the return on other factors that determine human capital. To a government, attempting to redistribute income from the rich to the poor in the least costly way, an education subsidy might offer a valuable additional instrument. Subsidizing education results in a compression of pre-tax wages, thus reducing the need for distortionary progressive taxation. In fact, one can show that in this type of world it is always optimal to combine a progressive income tax with an education subsidy (see Dur and Teulings, 2001). Efficient redistribution policy trades off the distortionary effect of progressive taxation and the distortions arising from education subsidies.

For plausible values of the supply and demand elasticities of human capital, subsidies to the education system of about the level that we observe empirically can be rationalized on the grounds of redistribution, even though in this framework redistribution is the only reason to subsidize education. This theory predicts that countries with more progressive tax systems should have higher levels of education subsidies, a prediction which is well in line with the observed pattern of education subsidies across OECD countries (Dur and Teulings, 2003). ${ }^{9}$

Imperfect substitution between worker types is crucial for this result. Previous studies have found that, for realistic values of the elasticity of substitution, imperfect substitution between types of labour does not make a great deal of difference for optimal income policy (see, for example, Feldstein, 1973; Stiglitz, 1982). Dur and Teulings argue that this negative conclusion is largely due to an unresolved technical problem. Typically these papers assume a production function with a discrete number of types (in practice, mostly two types). Teulings (2000) shows thatusing a production function with only two instead of a continuum of types yields a seriously downwardly biased estimate of the spill-over effects of minimum wages. Dur and Teulings claim that the same problem applies for supply and demand effects of an increase in the mean level of human capital, since large shifts in relative wages within each of the types are ignored.

A simple regression of the private return to schooling, taken from microestimates, on the average education level in different countries suggests that a higher education level indeed leads to a substantial decrease in the return to schooling. Teulings and van Rens (2003) find that if the average education level is higher by a year, the return to schooling in a country decreases by about 0.7 percentage points. They also derive relations between education and national income and inequality. Their estimation results imply that a 1-year increase in the stock of human capital reduces its return by about 1.5 percentage points, strengthening the results from the simpler estimates. ${ }^{10}$ This estimate is well in line with conventional estimates of the elasticity of substitu-

\footnotetext{
${ }^{8}$ If being rich were purely a matter of choice, there would be no need for redistribution.

${ }^{9}$ On top of this, increasing marginal rates may call for education subsidies. Staying in education longer yields a higher labour income during a shorter time span. Then, the increasing marginal rates imply that an equal lifetime income is taxed more heavily. Education subsidies can offset this distortion, see Bovenberg and Jacobs (2001). However, empirically, marginal tax rates tend to be rather flat.

${ }^{10}$ Teulings and van Rens (2003) also find clear evidence for skill-biased technological progress, raising the short-run return to education by about the same size as the effect of the increase in the average education level over the same period. This explains why the secular upward trend in the average education level of the work-force has not reduced the return to education.
} 
tion between low- and high-skilled workers (Katz and Murphy, 1992). ${ }^{11}$

The analysis of education subsidies as a redistributive device calls for a general subsidy to all levels of education. This redistribution policy contrasts sharply with the usual idea of compressing the wage distribution via compression of the distribution of human capital - that is, by putting special policy effort into raising the education of the least skilled. For example, the recent Luxembourg and Lisbon summits of the EU have focused the efforts for investment in human capital on raising the level of education of the least skilled. Such a policy relies on direct effects of investment in human capital. It is not clear, however, why subsidizing the human-capital acquisition of the poor would be preferable over generic income support. Standard economic theory suggests that it does not, unless one resorts to paternalistic arguments. Moreover, it is muchsimpler to raise everybody's skill level by a bit than to raise a particular group's skill level by a lot, as the distortions increase quadratically with the deviation from the market outcome. Finally, and perhaps most importantly, with imperfect substitution between skill types, subsidies to the humancapital acquisition of the poormight run into trouble. By the standard supply-and-demand argument outlined above, the additional human capital in the lower tail of the skill distribution is likely to reduce the wages for these skill types, at least partly undoing the effect of initial subsidy to the low skilled. The empirical study by Teulings and van Rens (2003) provides some, though far from conclusive, empirical evidence on this issue. They find an insignificant effect of the variance of the education distribution on income inequality, whereas they find a strong significant negative effect of the average education level on the return to human capital. These arguments suggest that the promotion of education at all levels may contribute more to a progressive income policy than policies that focus at the low levels only.

\section{(ii) Adverse Income Effect}

There is, however, an important counter-force which limits the redistributive effect of education subsi- dies. Because education and ability are complementary, high-ability types take up more education. Subsidies to all levels of education therefore predominantly favour the high-ability types, leading to a widening instead of a compression of the income distribution. One would like to subsidize the highability types on the margin to let them take up even more education, but not to subsidize them for inframarginal years of education that they would take anyway.

This direct effect of education subsidies on the income distribution, and the supply-and-demand effect through the return to education, work in opposite directions. Whether education should be taxed or subsidized depends on which effect dominates. If the supply-and-demand effect dominates, a subsidy is the optimal policy, since it reduces the return to education. If the complementarity effect dominates, a tax is the optimal policy, since education is a reasonable proxy for ability, just as income is. Which effect dominates depends essentially on three parameters: the elasticities of the supply and demand for human capital (the slopes of the supply and demand curves in Figure 2), and the degree of complementarity between ability and education. The higher the elasticities of demand and supply, and the lower the complementarity of ability and education, the more likely is the supply-and-demand effect to dominate the direct effect on income. Dur and Teulings $(2001,2003)$ provide a precise condition. Their review of some empirical studies on these parameters suggests that, in practice, both effects are of the same order of magnitude.

\section{CONDITIONING EDUCATION SUBSIDIES}

The conclusion of the previous paragraph suggests that if policy-makers want successfully to apply education outcomes for an efficient redistribution policy, they have to find ways to reduce the adverse direct effect on income. Therefore, if education subsidies are motivated by their redistributive effect, theory prescribes that the subsidy should be

\footnotetext{
11 Teulings and van Rens focus on labour earnings, ignoring capital income. The compressing effect of education on the income distribution may be even larger than implied by their estimates. Pellicer (2002), building on recent evidence showing that education is positively related to financial-market participation even when controlling for wealth and wage, proposes a model and some supporting evidence that most of the increase in stock-market participation in the USA from the 1960 s to the late $1980 \mathrm{~s} \mathrm{can} \mathrm{beattributed} \mathrm{toincreased}$ education levels. Apart froma direct welfare effect through better functioning of insurancemarkets, higher participation rates may further reduce inequality if the new participants (who experience an increase in financial income) are below the mean.
} 
conditioned on ability. Since ability is unobservable, the best we can do is to condition on some observable characteristic that is correlated with it. In this section we consider three candidates: schooling level, the student's own future income, and parental income.

\section{(i) Efficient Redistribution}

To fix ideas, we consider the log linear specification of income policy proposed by Dur and Teulings (2001),

$$
d=\delta_{0}+\delta_{y} y+\delta_{s} s
$$

where $d$ denotes the logarithm of a worker's (aftertax) disposable income, $y$ is log (pre-tax) labour income, and $s$ is the number of years of education of the worker. The parameters $\delta_{0}, \delta_{y}$, and $\delta_{s}$ describe the redistribution policy through income taxes and education subsidies. If $\delta_{y}=1$, the income tax is proportional with a constant marginal tax rate. If further $\delta_{0}=\delta_{s}=0$, then the tax rate is zero and disposable income equals labour income. The average tax rate increases with income if $\delta_{y}<1$, in which case the tax system is progressive. Taxes are regressive for $\delta_{y}>1$. Finally, $\delta_{s}$ measures the subsidy on education: education is taxed or subsidized for $\delta_{s}$ negative or positive, respectively.

If education subsidies can be conditioned on the level of schooling and on another variable, $z$, that is correlated with ability, the above log linear policy rule is extended with a quadratic term and a crossterm:

$$
d=\delta_{0}+\delta_{y} y+\left(\delta_{s}-\delta_{s z} z-\delta_{s s} s\right) s .
$$

The effect of this income policy can be analysed by comparing the marginal subsidy, which drives the favourable supply-and-demand effect, with the average subsidy per year of education, which drives the adverse complementarity effect favouring the high ability types:

marginal subsidy $=\delta_{s}-\delta_{s z} z-2 \delta_{s s} s$ average subsidy $=\delta_{s}^{s}-\delta_{s z}^{s z} z-\delta_{s s} s$.
If an observable variable $z$ were available, that is perfectly correlated to $s$ in equilibrium, for example $z=\alpha_{0}+\alpha_{1} s$, but that is nevertheless not affected by the individual's choices, then we can set $\delta_{s s}=-\alpha_{1} \delta_{s z}$ and $\delta_{s}=\alpha_{0} \delta_{s z}$ so that the average subsidy is zero for all $s$, while there still is a positive marginal subsidy $\alpha_{1} \delta_{s z}$. This would eliminate the adverse direct effect on income, while preserving the supply-anddemand effect. Notice that in this optimal policy, education subsidies would be decreasing in 'ability' $z$ but increasing in the education level chosen by the individual. $^{12}$

Obviously, such a perfect proxy for ability is not available. We consider three potential imperfect alternatives: parental income, the student's own future income, and the education level he or she attains. All three have advantages and disadvantages. The first alternative is to condition subsidies on the education level itself, $z=s$. Clearly, this choice of $z$ does not satisfy the condition that it is independent of the individual's choice of $s$ because $z$ and $s$ are identical. This policy can be described by $\delta_{z s}=0$ (no conditioning on any variable that is not affected by the individual's choices) and $\delta_{s s}>0$ (making the subsidy declining in the education level attained by the individual). The real-world meaning of this policy is to subsidize primary and secondary education more heavily than college. The disadvantages of such a policy are obvious from the equations above: the favourable marginal subsidy declines even faster than the adverse average subsidy. Hence, this kind of policy leaves a large part of the potential contribution of the subsidies to redistribution unexploited because it raises only educational attainment of the lower-ability types.

Conditioning on the student's own future income has disadvantages that are largely similar. First, similar to schooling $s, \log$ income $y$ does not satisfy the condition imposed on $z$, that it must not be affected by the individual's choice of $s$, since an increase in $s$ raises the worker's log labour income $y$. By itself, this reduces the effectiveness of conditioning on $y$. Compared to conditioning on $s$, conditioning on $y$ has the further disadvantage that it raises the marginal tax rate for highly skilled work-

\footnotetext{
${ }^{12}$ If $z$ would be affected by the individual's schooling choice, the expression for the marginal subsidy would include an additional term $-\alpha_{1} \delta_{s z} s=+\delta_{s s}$ for the proposed optimal policy, making the marginal subsidy equal to the average subsidy and eliminating the effect of conditioning the education subsidy on $z$.
} 
ers, and therefore distorts their labour-supply decision even further. Both the reduction in investment in human capital and the reduction in labour supply at the top of the ability distribution, reduce the relative supply of high-skilled workers, therebyleading to an adverse supply-and-demand effect.

Summarizing the results so far: neither conditioning on the attained education level nor on the student's own future labour income seems to contribute much to our goal of reducing adverse direct effects on income, while preserving the favourable supplyand-demand effects. In fact, starting from the formal model proposed in Dur and Teulings (2001), one can show that these types of non-linearities are not part of an efficientredistribution policy (calculations available from the authors on request). The exact results on the shape of the optimal income policy depend heavily on specific functional form assumptions, but it is clear (though perhaps surprising) that efficient redistribution does not offer an argument in favour of providing education subsidies only to low education levels or only to low-income students.

The third alternative, to condition education subsidies on parental income, might make better sense. This variable is the only one of the three alternatives that satisfies the condition that it is independent of the individual's choice of $s$. This type of policy tries to take advantage of the correlation between parents' and children's ability. When this correlation is high, then parental income, which is strongly correlated with parental ability, is a good proxy for the student's ability, and conditioning education subsidies on parental income may be a good way to reduce the adverse income effect. It enables the government to reduce inframarginal education subsidies to high-ability children who would choose a high schooling level also without any subsidies.

However, there are two disadvantages of conditioning on parental income. First, to the extent that the correlation of the ability of subsequent generations is imperfect, we introduce noise in the relation between the education subsidy and the ability of the individual. High-ability children of low-income parents receive too much subsidy and therefore take up too much education, whereas the reverse is true for low-ability children of high-income parents. Since the cost of distortions increases quadratically with the size of the marginal distortion, the net welfare cost of this over- and under-education is negative. The second disadvantage of conditioning on parental income is that parents might reduce their investment in schooling in order to retain the future entitlements of their children to education subsidies. ${ }^{13}$ This happens when inter-generational altruism is strong. But if inter-generational altruism is weak, or parents are short-sighted and do not understand how their education and effort decisions affect the amount of subsidy that their (future) children will receive, there are no disincentive effects of conditioning subsidies on parental income. In this case, conditioning subsidies on parental income is efficient.

The problem with this explanation is that by the same token, we would expect to see income taxes conditional on parental income instead of own income, since parental income is predetermined from the point of view of the individual (assuming not too much altruism), so that this conditioning does not yield distortions. In practice, we do not observe such tax systems. ${ }^{14}$

\section{(ii) Constraints from the Political Process}

In reality, education subsidies in many countries are conditioned on education level as well as on parental income. Primary and secondary education are often more heavily subsidized than tertiary education (OECD, 2003). Conditioning student support for students in tertiary education on parental income happens in many countries. Conditioning subsidies on the student's own income-for instance, by making repayment of subsidized student loans conditional on future income - happens in some countries, but is much less prevalent than conditioning on parental income. In the previous section, we offered a partial explanation using an efficiency argument that rests on the assumption that conditioning on the student's own income would distort his or her decision more than conditioning on the parents' income distorts their decisions.

\footnotetext{
${ }^{13}$ A similar effect shows up when education subsidies are conditional on parents' financial assets; see Feldstein (1995) for empirical evidence.

${ }^{14}$ With the possible exception of an inheritance tax.
} 
Another reason why conditioning on parental income is so popular might be a time-consistency problem in human-capital policy. Conditioning education subsidies on parental income only (instead of on both parental and own future income) may arise in a political-economic equilibrium as a result of a commitment problem of the government. Even though the conditioning distorts the labour-supply decisions of the parents, today's conditioning does not distort the parents' current investment in human capital, as these are sunk costs. Hence, when a political decision is taken on conditioning, only the distortionary effect on parents' current labour-supply decisions is taken into account. Obviously, in the long-run equilibrium, educational decisions will be distorted as well, as people anticipate that their children's education subsidy will be conditioned on their income.

As before, the problem of this explanation is that a similar argument would predict income taxes to be conditional on parental income instead of own income. That we do not observe these taxes based on parental income in reality, may be explained by 'ethical' considerations. Income-tax rates based on parental income may be perceived as a life-long bonus or punishment for being born in a poor or rich family. Since education subsidies become effective much earlier in life, and are temporary by nature, conditioning these on parental income may be perceived as more equitable.

\section{v. CONCLUSIONS}

In this paper we have evaluated two arguments for conditioning education subsidies on parental income. The first reason, which is prevalent in the literature, is that students from low-income families face credit constraints that prevent them from taking up an otherwise profitable education level. The empirical verdict on credit constraints is not yet out. It seems that there is some room for conditioning student support on parental income for this reason, but that other forms of redistribution to families with children (and not just families with children at college) are at least equally important to alleviate the effects of low-income background on educational attainment. We have also argued that if credit constraints are to be the justification for education subsidies, then an efficient way to subsidize education is to provide subsidized student loans rather than grants. Providing student support in the form of subsidized loans, with repayment conditional on future income, increases efficiency, since the government can diversify risks from investing in schooling that individual students cannot insure against.

The second reason for conditioning education subsidies builds on our earlier work that shows that education subsidies can work as a redistributive device and should be part of the mix of instruments to redistribute income as efficiently as possible. However, as ability and education are positively correlated, unconditional education subsidies also have an adverse income effect because they benefit mainly high-ability students. That provides a rationale for conditioning education subsidies on ability. Because ability is unobservable, the best we can do is to condition subsidies on an observable correlated with ability, such as parental income. This works best if there is not too much inter-generational altruism within the family, since then parents do not adjust their schooling decision so as to avoid a reduction in education subsidies their (future) children may receive. In the short run, when parents' investments in education are sunk, there is always an incentive to condition education subsidies on parental income, even when there is strong intergenerational altruism. Even though conditioning distorts the work decision of the parents, it does not distort the current parents' educational attainment as they have already completed their education. Hence, when a political decision is taken on conditioning, only the distortionary effect on parents' work decisions will be taken into account. Obviously, in the long-run equilibrium, educational decisions will be distorted as well, as people anticipate that their children's education subsidy will be conditioned on their income. Politicians' inability to commit to future policies may, therefore, imply that there is too much conditioning of education subsidies on parental income in practice. 


\section{REFERENCES}

Acemoglu, D., and Pischke, J. S. (2001), 'Changes in the Wage Structure, Family Income, and Children's Education', European Economic Review, 45(4-6), 890-904.

Benabou, R. (1996), 'Inequality and Growth', NBER Macro Annual 1996, 11-74(alsoavailable as NBER Working Paper 5658).

- (2000), 'Unequal Societies: Income Distribution and the Social Contract', American Economic Review, 90(1), 96-129.

(2002), 'Tax and Education Policy in a Heterogeneous-agentEconomy: WhatLevels of Redistribution Maximize Growth andEfficiency?', Econometrica, 70(2),481-517.

Bovenberg, A. L., and Jacobs, B. (2001), 'Redistribution and Education Subsidies Are Siamese Twins', CEPR Discussion Paper No. 3309.

Cameron, S. V., and Heckman, J. J. (1998), 'Life Cycle Schooling and Dynamic Selection Bias: Models andEvidence for Five Cohorts of American Males', Journal of Political Economy, 106(2), 262-333.

Card,D.(2001), 'Estimating the Return to Schooling:Progress on some PersistentEconometric Problems',Econometrica, 69(5), $1127-60$.

Carneiro, P., and Heckman, J. J. (2002), 'The Evidence on Credit Constraints in Post-secondary Schooling', The Economic Journal,112(482), 705-34.

Department of Education and Science (2003), 'Supporting Equity in Higher Education: A Report to the Minister of Education and Science', Dublin, available at http://www.education.ie/servlet/blobservlet/ he_supporting_equity.pdf

Dur, R., and Teulings, C.N. (2001), 'Education and Efficient Redistribution', Tinbergen Institute Discussion Paper 01090/3.

- - (2003), 'Are Education Subsidies an Efficient Redistributive Device?', Tinbergen Institute Discussion Paper 03-024/3, forthcoming in: J. Agell, M. Keene, and A. Weichenrieder(eds), Labor MarketInstitutions and Public Regulation, Cambridge, MA, MIT Press, 2004.

Dynarski, S. (2002), 'The Behavioral and Distributional Implications of Aid for College', American Economic Review, 92(2), AEA Papers and Proceedings on 'The Consequences of Lowering the Cost of College', 279-85.

Feldstein, M. S. (1973), 'On the Optimal Progressivity of the Income Tax', Journal of Public Economics, 2(4), 35776.

- (1995), 'College Scholarship Rules and Private Saving', American Economic Review, 85(3), 552-66.

Galor, O., and Moav, O. (2000), 'Ability-biased Technological Transition, Wage Inequality, and Economic Growth', Quarterly Journal of Economics, 115(2), 469-97.

- Zeira, J.(1993), 'Income Distribution and Macroeconomics', Review of Economic Studies, 60(1), 35-52.

Jacobs, B., and van Wijnbergen, S. J. G. (2003), 'Optimal Financing of Education with Capital and Insurance Market Imperfections', University of Amsterdam, mimeo.

Janeba, E. (2000), 'Trade, Income Inequality, and Government Policies: Redistribution of Income or Education Subsidies?', NBER Working Paper 7485.

Katz,L.F., and Murphy,K.M.(1992), 'changes in Relative Wages, 1963-1987:Supply and Demand Factors', Quarterly Journal of Economics, 107, 35-78.

Keane, M. P., and Wolpin, K. I. (2001), 'The Effect of Parental Transfers and Borrowing Constraints on Educational Attainment', Penn Institute for Economic Research Working Paper 01-018.

Krueger, A. (2004), 'Inequality: Too Much of Good Thing', in J.Heckman and A. Krueger(eds), Inequalityin America: What Role for Human Capital Policies, Cambridge, MA, MIT Press.

Maoz, Y. D., and Moav, O. (1999), 'Intergenerational Mobility and the Process of Development', The Economic Journal, 109(458), 677-97.

Mayer, S. E. (1997), What Money Can't Buy: Family Income and Children's Life Chances, Boston, MA, Harvard University Press.

- (2002), 'The Influence of Parental Income on Children's Outcomes', Ministry of Social Development, Wellington, available at http://www.msd.govt.nz/documents/publications/csre/influenceof-parentalincome.pdf

NCES (2003), 'How Families of Low- and Middle-income Undergraduates Pay for College: Full-time Dependent Students in 1999-2000', National Center for Education Statistics, available at http://nces.ed.gov/pubsearch/ pubsinfo.asp?pubid $=2003162$

OECD (2003), Education at a Glance, Paris, Organization for Economic Cooperation and Development. 
Owen, A.L., and Weil, D.N.(1998), 'Intergenerational Earnings Mobility, Inequality and Growth', Journal ofMonetary Economics, 41(1), 71-104.

Pellicer, M. (2002), 'Education and Financial MarketParticipation', European University Institute, mimeo.

Persson, T., and Tabellini, G. (1994), 'Is Inequality Harmful for Growth? Theory and Evidence', American Economic Review, 48,600-21.

Plug, E., and Vijverberg, W.(2003), 'Does Family IncomeMatter for Schooling Outcomes? Using Adoption as a Natural Experiment', University of Amsterdam/University of Texas atDallas, mimeo.

Shea, J. (2000), 'Does Parents' Money Matter?', Journal of Public Economics, 77(2), 155-84.

Stanley, M. (1999), 'College Education and the Mid-century GI Bills', Harvard University, mimeo.

Stiglitz, J.E. (1982), 'Self-selection and Pareto Efficient Taxation', Journal of Public Economics, 17(2), $213-40$.

- Weiss, A.(1981), 'CreditRationing in Markets with ImperfectInformation', American Economic Review, 71(3), 393-410.

Teulings, C.N.(2000), 'Aggregation Bias in Elasticities of Substitution and the Minimum Wage Paradox', International Economic Review, 41(2), 359-98.

- van Rens, T. (2003), 'Education, Growth and Income Inequality', Tinbergen Institute Discussion Paper 02-001/ 3 and CEPR Discussion Paper 3863. 